\title{
Solar Energy Potentials in Southeastern European Countries: A Case Study
}

\author{
Abdulsalam Alkholidi*ł, Habib Hamam** \\ *Telecommunications Engineering Department, Faculty of Engineering, Canadian Institute of Technology, Rr. Andon Zako \\ Cajupi, (Near Wilson Square), Tirana, Albania \\ **Optics in Information and Communication Technologies, Faculty of Engineering, Moncton University, Campus de \\ Moncton, Pavillon Léopold-Taillon, 18, avenue Antonine-Maillet, Moncton, NB Canada E1A 3E9 \\ (abdulsalam.alkholidi@cit.edu.al, habib.hamam@umoncton.ca) \\ ¥Corresponding Author; Abdulsalam Alkholidi, Rr. Andon Zako Cajupi, (Near Wilson Square), Tirana, Albania \\ Tel/Fax: +355 42229778 \\ abdulsalam.alkholidi@cit.edu.al \\ Received:21.05.2019 Accepted: 09.06.2019
}

\begin{abstract}
The climate in Southeastern European countries is relatively similar to that of the Middle East and North Africa, where the annual sun irradiation is theoretically high according to SolarGIS data. Today, the photovoltaic systems technology sector is exponentially expanding in the international energy market. The aim of this paper is to study, compare, and analyze this important field in related countries and propose solutions to develop and encourage a solar energy market in Albania, where the economy has been gradually increasing in the last ten years. The potential for a renewable energy sector in Albania is promising, mainly because of the important presence of wind and solar energy resources. An additional objective of this study is to try to apply the results obtained in similar countries in the Balkans to increase the socioeconomic benefits and the creation of job opportunities in the country, as well as contributing to the protection of the environment and economic growth. In this paper, we discuss the importance of exploiting photovoltaic systems in mountainous regions and villages -where public electricity is unavailable - to be widely used in heating, lighting, and irrigation, as well as to support grid systems. In addition, the advantages of photovoltaic technology are introduced and illustrated to motivate public establishments and governmentowned electrical sectors to use and develop this technology.
\end{abstract}

Keywords heating, education, clinics, home lighting, irrigation, mountainous areas, floating solar.

\begin{tabular}{|c|c|c|}
\hline $\begin{array}{l}\text { Nomenclatures } \\
\text { Abbreviations }\end{array}$ & & Greek symbols \\
\hline AM0 & Air Mass zero & Kelvin \\
\hline $\mathrm{AU}$ & Astronomic Unit & \\
\hline $\mathrm{c}$ & Speed of light $(\mathrm{c}=$ about $3 * 108 \mathrm{~m} / \mathrm{s})$ & Polar angle \\
\hline $\mathrm{CSP}$ & Concentrating Solar Thermal Power & \\
\hline EPS & Energy performance certificates & Azimuth \\
\hline GISS & Goddard Institute for Space Studies & \\
\hline GISTEMP & GISS Surface Temperature Analysis & Speed of Plank's constant \\
\hline GWdc & Giga Watts-dc & \\
\hline MERRA & $\begin{array}{l}\text { Modern Era Retrospective Analysis for } \\
\text { Research and Application }\end{array}$ & Frequency \\
\hline MW & Megawatt & Wavelength \\
\hline NASA & $\begin{array}{l}\text { National Aeronautics and Space } \\
\text { Administration }\end{array}$ & Hemisphere \\
\hline $\begin{array}{l}\text { PERC } \\
\text { PV }\end{array}$ & $\begin{array}{l}\text { Passivated Emitter and Rear Cell } \\
\text { Photovoltaic }\end{array}$ & Prefixes \\
\hline $\mathrm{W}$ & Watts & Whole surface \\
\hline Le & Radiance & \\
\hline $\mathrm{E}$ & Energy & Photons \\
\hline M & Mass & \\
\hline$P$ & Power $[\mathrm{W}]$ & \\
\hline $\mathrm{E}$ & Energy $[\mathrm{kWh}]$ & \\
\hline
\end{tabular}




\section{Introduction}

Radiant energy from the Sun constitutes the Earth's primary source of energy. This energy is measured in irradiance, which is the amount of light energy received by a surface per unit area. Put differently, irradiance can be defined as the output of light energy from the sun as it is measured on Earth. With photonic wavelengths ranging from X-rays and gamma rays, this light energy is made visible by means of infrared and radio technology [1].

Today, photovoltaic technology has become one of the world's most important source of power in generating infinite energy. According to [2], "the annual market increased nearly $50 \%$ to at least $75 \mathrm{GWdc}$ - equivalent to more than 31,000 solar panels installed every hour - raising the global total to at least $303 \mathrm{GWdc}$. In 2016, $110 \mathrm{MW}$ of concentrating solar thermal power (CSP) capacity came online, bringing global capacity to more than $4.8 \mathrm{GW}$ by year's end [2] This was the lowest annual growth rate in total global capacity in 10 years, at just over $2 \%$. Even so, CSP remains on a strong growth trajectory, with as much as 900 MW expected to enter operation during the course of 2017."

Photovoltaic cells is a solar-energy technology that converts sunlight into electricity (PV effect) by using semiconductor conductivity widely known as PV cells. Solar cells are configured as a PV panel or a module that can be combined as a PV system operating from watts - from an electricity power output - to several megawatts - from power stations [3].

Figure 1 projects global temperature and precipitation rates in the years leading to 2100, according to various greenhouse gases emission rates. NASA developed these projections by combining historical data with the results from climate simulations using state of the art technology.

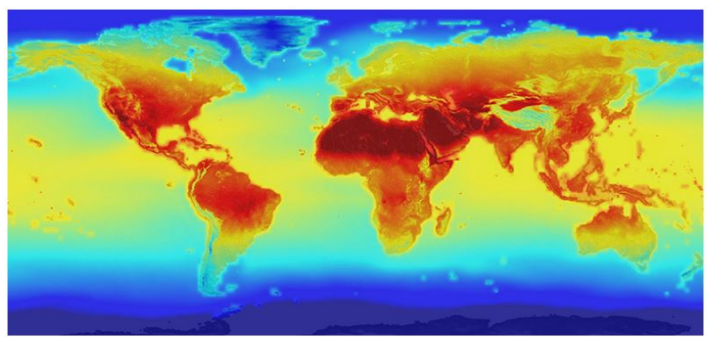

Fig. 1. The new NASA global data set combines historical measurements with data from climate simulations using the best available computer models to provide forecasts of how global temperature (shown here) and precipitation might change up to 2100 under different greenhouse gas emissions scenarios [4].

Figure 2 shows the GISTEMP monthly temperature anomalies in a 1880 to 2018 mean seasonal cycle.

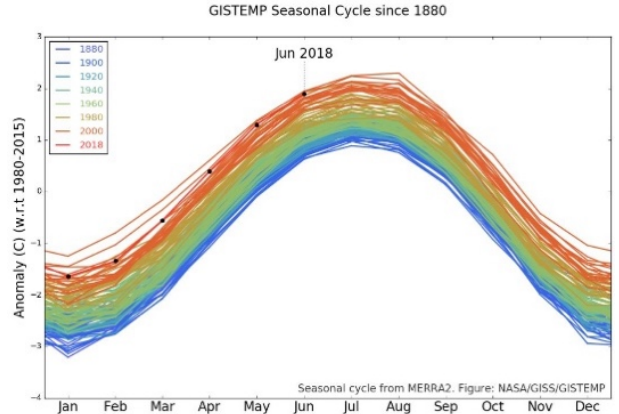

Fig. 2. The GISTEMP monthly temperature anomalies in a 1880 to 2018 mean seasonal cycle (seasonal cycle from MERRA2) [5].

According to the National Aeronautics and Space Administration, Goddard Institute for space Studies "April 2018 was the third warmest April on record," as it was " $0.86^{\circ} \mathrm{C}$ warmer than the average April of the 1951 1980 period; this value is in line with the $1.8^{\circ} \mathrm{C} /$ century rate of increase of the past 40 years." Table 1 demonstrates the warmer months compared to the average, where the results show that April 2016 and 2018 were the warmest.

Table 1. The warmer months compared to the average value

\begin{tabular}{|l|l|l|l|l|l|}
\hline $\begin{array}{l}\text { Month and } \\
\text { year }\end{array}$ & $\begin{array}{l}\text { April } \\
2010\end{array}$ & $\begin{array}{l}\text { June } \\
2015\end{array}$ & $\begin{array}{l}\text { April } \\
2016\end{array}$ & $\begin{array}{l}\text { April } \\
2017\end{array}$ & $\begin{array}{l}\text { April } \\
2018\end{array}$ \\
\hline $\begin{array}{l}\text { Warmer than } \\
\text { the } \\
\text { average value }\end{array}$ & $\begin{array}{l}+0.84 \\
{ }^{\circ} \mathrm{C}\end{array}$ & $+0.80^{\circ} \mathrm{C}$ & $\begin{array}{l}+1.07 \\
{ }^{\circ} \mathrm{C}\end{array}$ & $\begin{array}{l}+0.92 \\
{ }^{\circ} \mathrm{C}\end{array}$ & $+0.86^{\circ} \mathrm{C}$ \\
\hline
\end{tabular}

Global warming, or climate change, is defined as the drastic change in temperature over the last few years comparatively to the historical trend, as demonstrated in Table 1. This trend will continue and even worsen if policymakers do not adopt the measures necessary to protect the planet, such as limiting gas emission and minimizing its sources as much as possible and introducing preventative solutions. One solution is to further develop renewable energy technology, expand its use, encourage investment in renewable energy resources and minimize the manufacture of polluting objects.

For solar modules, efficiency is the key metric. Put simply, increasing the efficiency consequently increases the power rating. EPCs pay for this power rating, which charges a number of dollars per watt.

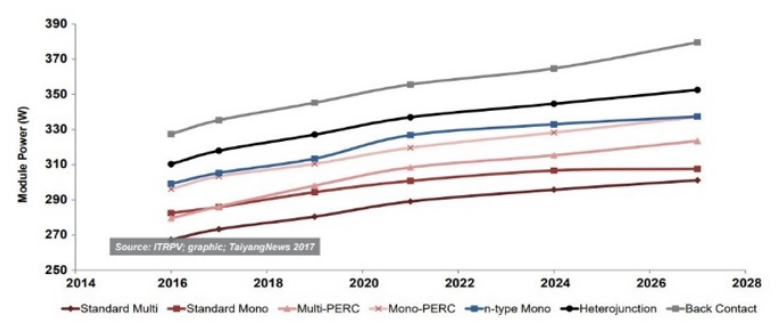

Fig. 3. Power rating of different module technology [6].

Figure 3 presents the power gain potential: over the next 10 years the power ratings of solar modules are expected to 
increase by an average of approximately $1.3 \%$ /year; back contact modules and multi-PERC are expected to record the highest increase - close to $1.6 \%$ per year.

\section{Literature Review}

According to a study by IRENA, published in February 2018, renewable energy systems are rapidly becoming less expensive than conventional power production technology. Therefore, fossil fuel prices have fallen in the last decade and renewable energy technology prices are quickly plummeting thanks to the development of a stronger renewable energy global market. For example, solar PV systems and solar panel technology in Europe has decreased by approximately $80 \%$ from 2010 to 2016 (IRENA, 2016c). Consequently, this decrease enables competitive generation prices, even in countries with low-quality solar resources. In June 2017, for instance, a utility-scale solar PV auction in Germany yielded an average cost of 5.6 Eurocents per $\mathrm{kWh}$ [7].

An approximation of payback time of different sized photovoltaic panels in different locations was estimated in a paper published by Giovanni Mazzanti. The study takes into account the time required to evaluate the incentive mechanism and the PV market economy. The objective of the published paper is to determine if the PV system is equivalent to grid systems. The assessment demonstrates the fast growth of PV markets in the last decade worldwide and particularly in Italy. This method of PV can be a standard of developing solar energy systems in the world as indicated in the paper. The study estimates that the economic situation could lead to a decrease in the PV market technology. However, the study also foresees a possible delay in the progress of Grid Parity, though, its finalization is inevitable $[8]$.

A series of long-term surface solar radiation (SSR) in Athens is presented in this published work. The measurements of the surface solar radiation were implemented between 1954 to 2012. The study used a record sunshine duration between 1900 to 1953 to rebuild monthly SSR. After having analyzed the data, the results showed that a small change of $0.02 \%$ in SSR was registered. Compared to several studies developed in the Mediterranean area, this Athenian study reported a lower percentage of SSR change. The study also demonstrates that changes in SSR of all-sky and clear-sky conditions after 1994 are largely the result of aerosol load changes, although cloudiness is a partial factor [9].

The work published by Roberto L. Arantegui and Arnulf Jäger-Waldu introduces the deployment of solar and wind energy in the EU and the leading strategy behind this growth. As one of the largest economies in the world, the EU plans to reach $27 \%$ of its energy production from green sources by 2030 . In 2016 , over $12 \%$ of the EU's electricity demand was generated by solar and wind sources - a little less than half of the 2030 target As the authors indicate, the data used in this research is collected from different sources, establishments, government officials and policymakers to support the progress of solar and wind energy, proving once again that grey data is crucial to research in this domain [10].

This paper focuses on solar energy potential and its merits and demerits. The development of modern photovoltaic technology is considered as one of the solutions to meeting the increasing demand for electrical energy production. Researchers explored the fast growth of solar technology and the several technical barriers that persist, mainly a low PV cell efficiency, a low performing balance of systems and economic obstacles, such as the high cost and shortage of funding mechanisms [11].

As indicated in the report [2], solar PV has become the primary source of new power capacity in a number of major economies. In 2017 - a particularly fruitful year for PV systems technology - more capacities of this technology were developed than other power productions, such as fossil fuel and nuclear power [12].

"In the year 2017, 29 countries passed the GW mark with respect to the PV installed capacity. Seven countries now have more than $10 \mathrm{GW}$ of total capacity, four more than 40 GW and China alone represented $131 \mathrm{GW}$. Germany, which used to lead the rankings for years, lost its leading position in 2015 and now ranks fourth (42 GW), with Japan third (49 $\mathrm{GW})$ and the USA second (51 GW). With more than 111 GW of total capacity, Europe is now significantly behind the Asian leader that runs at least $219 \mathrm{GW}$, and much more to come in the coming years" [13].

According to IRENA, as of late 2017, hydro power generation capacity remains the most used renewable generation in the world, with $53 \%(1,152 \mathrm{GW})$ of the share, while wind energy ranks in second place with $23 \%(514$ $\mathrm{GW}$ ) of the share, as demonstrated in Fig. 5. Overall, solar energy production ranks in third place, with $18 \%$ (397 GW) of the share, while the remaining renewable energy accounts for $6 \%$ of all production. Globally, renewable generation capacity amounts to $2,179 \mathrm{GW}$ [14].

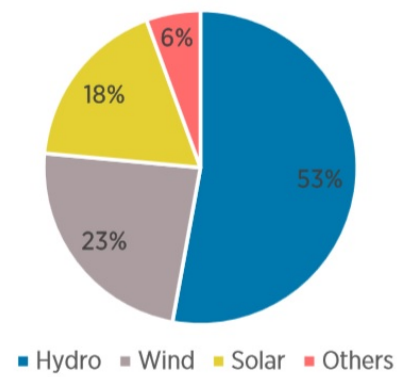

Fig. 5. Renewable generation capacity by energy source.

In 2016, the global solar cell manufacture reached 79 to 84 $\mathrm{GW}$, while it increased to 90 to $95 \mathrm{GW}$ in 2017. Figure 6 shows the global PV cell/module production between 2005 and 2017. 


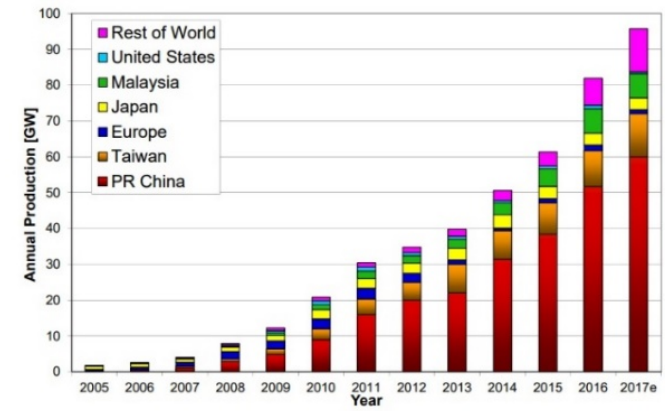

Fig. 6. World PV cell/module production from 2005 to 2017 (estimate) [15-16].

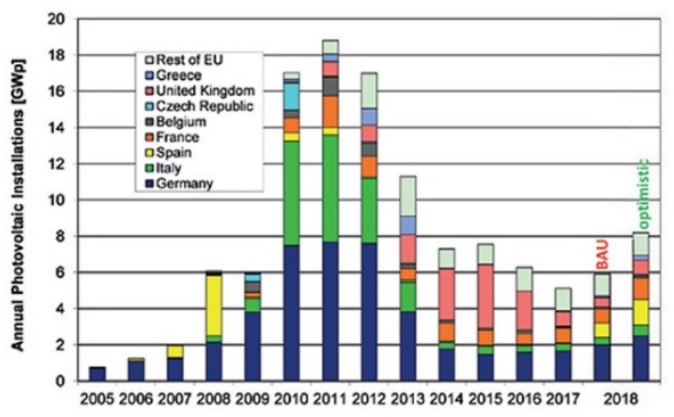

Fig. 7. Annual photovoltaic installation in the European Union [17].

Figure 7 illustrates the annual photovoltaic installation (GWp) in the EU from 2005 to 2018. Up until 2011, there has been an exponential increase, which began to falter afterwards, although the total installed capacity recorded in 2017 was $108 \mathrm{GW}$ approximately. The installation span in the last four years starts from approximately 5.1 to 7.6. We note that the average annual target has decreased comparatively to the growth that occurred from 2010 to 2011. Accordingly, new policies to develop this important sector are needed to increase the annual photovoltaic installation in the European Union [17].

The annual solar installations in Europe, in 2017, increased by $28 \%$ (with Turkey leading the solar market), with a total of solar energy production of approximately $8.61 \mathrm{GW}$; while in the 2016, the installation increased by only $6 \%$, rising from 5.69 to 6.03 GW according to Solar Power Europe [20]. The top 5 European markets in 2017 are presented in Table 2.

Table 2. Top 5 European Solar Markets 2017 [18].

\begin{tabular}{|c|c|c|c|c|c|c|}
\hline $\begin{array}{l}\text { Country } \\
\text { Name }\end{array}$ & $\begin{array}{l}\mathrm{R} \\
\mathrm{O} \\
\mathrm{E}\end{array}$ & Turkey & $\begin{array}{l}\text { Germ } \\
\text { any }\end{array}$ & UK & $\begin{array}{l}\text { Fran } \\
\text { ce }\end{array}$ & $\begin{array}{l}\text { Netherlan } \\
\text { ds }\end{array}$ \\
\hline $\begin{array}{l}\text { Solar } \\
\text { Market }\end{array}$ & $\begin{array}{l}2 \\
8 \\
\%\end{array}$ & $21 \%$ & $20 \%$ & $\begin{array}{l}11 \\
\%\end{array}$ & $10 \%$ & $10 \%$ \\
\hline
\end{tabular}

Renewable generation capacity in Europe in 2017 is shown in Table 3.

Table 3. Renewable generation capacity in Europe [14].

\begin{tabular}{|l|l|l|l|}
\hline Capacity & Global share & Change & Growth \\
\hline $512 \mathrm{GW}$ & $24 \%$ & $+24 \mathrm{GW}$ & $+4.8 \%$ \\
\hline
\end{tabular}

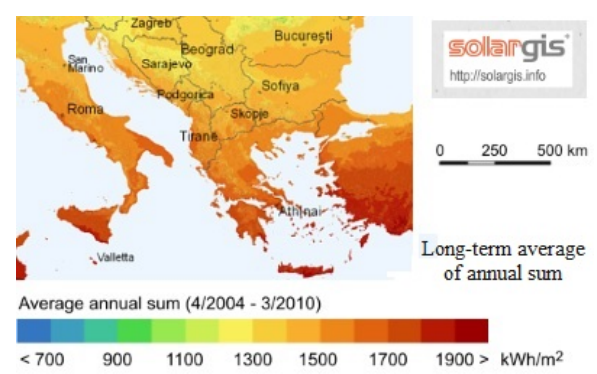

Fig. 8. Map of the average annual download surface solar irradiation in Southeast Europe [19].

Figure 8 shows the long term average of annual sum surface solar radiation in Southeast Europe. Seven different solar radiation scales are explored in the region starting from 700 to $1900 \mathrm{kWh} / \mathrm{m}^{2} /$ year. Accordingly, development of solar energy systems in the region is promising compared to north and central Europe, as indicated in the previous map, as radiation levels are a key factor in increasing the efficiency and economic feasibility of PV systems.

Finally, we quote the paper published by Stefan Dunjic et al. [20]. This paper illustrates the growth, consumption and share of renewable energy in the related countries. Some calculations are done to illustrate the shares for two years, namely 2010 and 2011. Subsequently, these numbers are combined with those from the years 2009, 2012 and 2013 to create a linear trend forecast.

The results show the growth of renewable energy outside of the European Union and its link to the complex political situation in the Balkan countries, including the gas crisis of 2009. Consequently, decision makers developed renewable energy markets to avoid the existing and future energy crisis.

\section{Methodology}

The sun is at the center of the solar system and consists mainly of hydrogen and helium. Its mean distance from the Earth is approximately $149,600,000 \mathrm{~km}$ (the astronomic unit, $\mathrm{AU}$ ), its temperature (at the center) is about $15.000,000 \mathrm{~K}$ and it radiates $3.8 * 1026 \mathrm{~W}$ of energy, of which the Earth receives only $1.7 * 1018 \mathrm{~W}$. The solar radiation spectrum is introduced in Fig. 4. 


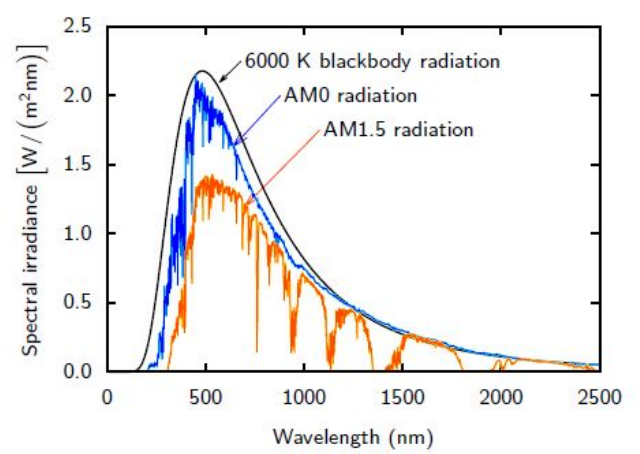

Fig. 4. Different solar spectra [21].

Figure 4 shows the spectrum of a blackbody at $6000 \mathrm{~K}$. But outside the Earth's atmosphere, the spectrum - called AM0 spectrum since the photon travels across no or "zero" atmosphere - is drastically different. AM0 is also illustrated in Fig. 4. The irradiance at AM0 is

$$
L_{e}(A M 0)=1361 W \cdot m^{-2}
$$

The optical air mass refers to the ratio of sunlight through this minimal distance. When the Sun sits at its zenith, the spectrum is AM1. As such, we can calculate the air mass when the sun is at an any angle ${ }^{\theta}$ from the zenith using the following formula:

$$
\text { Air Mass }=\frac{1}{\cos \theta}
$$

Using Einstein's equation, the difference is converted into energy:

$$
E=m c^{2}
$$

Radiometry is the science concerned with measuring electromagnetic radiation and hence more specifically light. This is particularly important to photovoltaic processes that convert sunlight into electricity, as the "amount of energy" must defined mathematically first. To determine the amount of energy per unit time, we must apply the following formula:

$$
P=\frac{d E}{d t}
$$

where $\mathrm{P}$ is the power and $\mathrm{E}$ the amount of energy.

To calculate the total power over the entire surface, we must the apply the following formula:

$$
P=\int_{A} \int_{2 \pi} L_{\theta} \cos \theta d \Omega d A
$$

The presence of $\cos \theta$ is indicative of the importance of the projection of $\mathrm{dA}$ on $(\theta, \varphi)$ rather than $\mathrm{dA}$ itself. This is essentially a manifestation of the Lambert cosine law. Le refers to the radiance, of which the physical dimension can be expressed as:

$$
\left[L_{e}\right]=W \cdot m^{-2} \cdot s r^{-1}
$$

Sunlight is a portion of electromagnetic radiation given off by the sun, in particular infrared (700 nm to $1 \mathrm{~mm})$, with a frequency that ranges from $430 \mathrm{THz}$ to $300 \mathrm{GHz}$ approximately, visible light spans (from 380 to $780 \mathrm{~nm}$ ), and ultraviolet light (10 to $400 \mathrm{~nm}$ ).

The electromagnetic spectrum is defined in terms of energy, wavelengths or frequency, of which the latter two are related by the following equation [22]:

$$
\lambda=\frac{c}{v}
$$

where $\mathrm{c}$ is the speed of light $(2.998 * 108 \mathrm{~m} / \mathrm{s})$.

As Albert Einstein concluded in 1905, under Plank's law, light travels in quanta of energy with the size expressed as follows:

$$
E_{p h}=h v
$$

where $h$ is the speed of Plank's constant. The unit of wavelength is expressed in meters $(\mathrm{m})$, very often in microns (denoted by $\mu \mathrm{m}$ and equal to $10-6 \mathrm{~m}$ ) or in nanometers (denoted by $\mathrm{nm}$ and equal to $10-9 \mathrm{~m}$ ). These quanta are called photons. In terms of classical mechanics, it can be said that light shows the behavior of particles. Refer to references for more details [21].

PV cell technology has improved gradually over the last decade and the infinite power generation sector has a significant application worldwide, mainly due to its low cost (dropping cost of silicon solar cells), the high-efficiency of solar cells and a global shift towards renewable energy sources. Hence, research priorities include:

- Reducing the PV panel cost and increasing its conversion efficiency.

- $\quad$ Reducing the cost of battery storage for PV power systems.

- Innovating a new generation of solar photovoltaic technology.

\section{Renewable Energy Sector Overview of Albania, BiH and Kosovo}

The Western Balkan countries have an obligation to meet a set of specific renewable power generation targets by 2020 . The targets involve different renewable sources, namely hydro, wind and solar, and also take into account the total energy consumption. $\mathrm{BiH}$ has set the highest percentage, $40 \%$, closely followed by Albania at $38 \%$, Montenegro at $33 \%$, Serbia at $27 \%$, Kosovo at $25 \%$ and finally Macedonia at $21 \%$ [23].

Progress towards these targets varies across countries: while Macedonia has nearly reached $95 \%$ of its set goal, Kosovo has only progressed by $17.74 \%$. Serbia has recorded the second highest progress at $81.28 \%$; $\mathrm{BiH}$ comes in third place at $77.54 \%$, closely followed by Albania at $74.06 \%$ and Montenegro at $65.72 \%$. Table 4 introduces the RES target fulfillments (Albania, $\mathrm{BiH}$, and Kosovo). 
Table 4. RES target fulfillments (Albania, BiH, and Kosovo)

\begin{tabular}{|c|c|c|c|c|c|c|}
\hline $\begin{array}{l}\text { RES } \\
2020 \\
\end{array}$ & \multicolumn{2}{|c|}{$\begin{array}{l}\text { Albania } \\
(\mathbf{3 8 \%})\end{array}$} & \multicolumn{2}{|c|}{$\mathrm{BiH}(40 \%)$} & \multicolumn{2}{|l|}{$\begin{array}{l}\text { Kosovo } \\
(25 \%) \\
\end{array}$} \\
\hline RES & $\begin{array}{l}\text { Target } \\
\text { (MW) }\end{array}$ & $\begin{array}{l}\text { Reac } \\
\text { hed } \\
2015\end{array}$ & $\begin{array}{l}\text { Target } \\
(\mathrm{MW})\end{array}$ & $\begin{array}{l}\text { Reac } \\
\text { hed } \\
2015\end{array}$ & $\begin{array}{l}\text { Target } \\
\text { (MW) }\end{array}$ & $\begin{array}{l}\text { Reac } \\
\text { hed } \\
2015\end{array}$ \\
\hline RES & & & & & & \\
\hline $\begin{array}{l}\text { Hydr } \\
\text { o }\end{array}$ & 2,324 & $\begin{array}{l}1,79 \\
7\end{array}$ & 2,700 & $\begin{array}{l}2,15 \\
0\end{array}$ & 240 & $\begin{array}{l}71.9 \\
4\end{array}$ \\
\hline Wind & 30 & 0 & 33 & 0.3 & 150 & 1.35 \\
\hline Solar & 50 & 0 & 16.2 & 8.2 & 10 & 0.15 \\
\hline $\begin{array}{l}\text { Biom } \\
\text { ass }\end{array}$ & 5 & 0 & 35.7 & 1 & 14 & 0 \\
\hline $\begin{array}{l}\text { Total } \\
\text { MW }\end{array}$ & 2,409 & $\begin{array}{l}1.79 \\
7\end{array}$ & $2,784.9$ & $\begin{array}{l}2,15 \\
9.5 \\
\end{array}$ & 414 & $\begin{array}{l}73.4 \\
4\end{array}$ \\
\hline $\begin{array}{l}\text { Perce } \\
\text { ntage } \\
(\%) \\
\text { reach } \\
\text { ed }\end{array}$ & \multicolumn{2}{|c|}{$74.60 \%$} & \multicolumn{2}{|l|}{$77.54 \%$} & \multicolumn{2}{|l|}{$17.74 \%$} \\
\hline $\begin{array}{l}\text { Sourc } \\
\text { es }\end{array}$ & $\begin{array}{c}\text { IRE } \\
\text { NA } \\
201 \\
7 \\
(\mathrm{Ta} \\
\text { ble } \\
4.2)\end{array}$ & & $\begin{array}{c}\text { NRE } \\
\text { AP, } \\
\text { IREN } \\
\text { A } \\
\text { tab } \\
\text { le } \\
4.4\end{array}$ & & $\begin{array}{l}\text { NR } \\
\text { EAP }\end{array}$ & \\
\hline
\end{tabular}

4.1

Solar Potential in Albania

Located between latitudes $39^{\circ} 38^{\prime}-42^{\circ} 38^{\prime}$ and longitudes $19^{\circ} 16^{\prime}-21^{\circ} 04^{\prime}$, Albania is a western Balkan country with significant renewable energy potential from hydro, wind and solar resources. It is surrounded by the Adriatic and Ionian seas at the West, Macedonia to the East, Kosovo to the Northeast, Montenegro to the Northeast and Greece to the South [24]. Its solar irradiation potential is promising, as the sunshine irradiation varies from $1200 \mathrm{kWh} / \mathrm{m} 2$ in the Northeast (Bajram Curri, Kruje, Kukës, Peshkopi, and Pukë) up to $1600 \mathrm{kWh} / \mathrm{m} 2$ in the Myzeqe area. In the Northwest, the quantity of solar irradiation varies from $1500 \mathrm{kWh} / \mathrm{m} 2 \mathrm{up}$ to $1700 \mathrm{kWh} / \mathrm{m} 2$ a year, as recorded in the following cities: (Durrës, Kavaja, Fier, Volorë, Vlora, Saranda, Tirana, and Berate) (Fig. 9) [25-26]. Solar radiation varies regionally, with the lowest daily average of $3.2 \mathrm{kWh} / \mathrm{m} 2$ being recorded in the Northeast and a high of $4.6 \mathrm{kWh} / \mathrm{m} 2$ in the Southwest. Hence, the average daily solar irradiation in Albania is about $4.1 \mathrm{kWh} / \mathrm{m} 2$; these statistics show that solar energy in Albania is available and considerable. The average sunshine is of 2400 hours/per year, while the Western regions receive more than 2500 hours (Fier has a record of 2850 hours) [25].

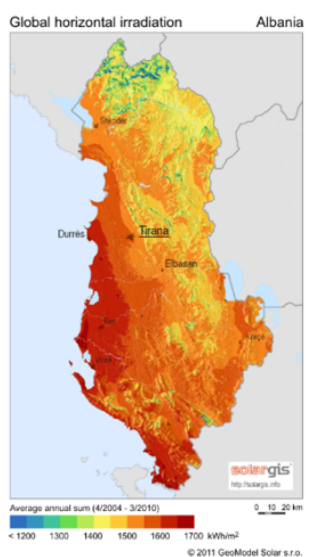

Fig. 9. Solar irradiation map of Albania, SolarGIS 2011.

Thus, the irradiation and PV electricity potential in Albania is promising. There is great potential to expand grid-based PV systems throughout Albania for heating, lighting, irrigation, telecommunication, medical, and educationrelated purposes. It can also be expanded in villages and mountainous areas (Korab, 2764 m, Maja Jezercë, 2694 m, Radohima, 2568 m, Tomorr, 2416 m, Maja e thatë, 2406 m, Shkëlzen, 2404, and Koritnik, 2393m, ASL, etc) [27]. The PV systems market developed rapidly in Albania over the last ten years thanks to political stability in the country and relative economic growth.

As demonstrated in Fig. 10, the hot season in Koplik in Northwest Albania [27] started June $14^{\text {th }}$ and ended September $9^{\text {th }}$ and averaged a daily high of $82^{\circ} \mathrm{F}$. With a recorded high of $90^{\circ} \mathrm{F}$ and a low of $70^{\circ} \mathrm{F}$, August 4 was the hottest day of the year. The cool season started November $21^{\text {st }}$ and ended March $11^{\text {th }}$ and averaged a daily high below $57^{\circ} \mathrm{F}$; the coldest day of the year was January 13 , in which temperatures reached a low of $34^{\circ} \mathrm{F}$ and a high of $49^{\circ} \mathrm{F}$.

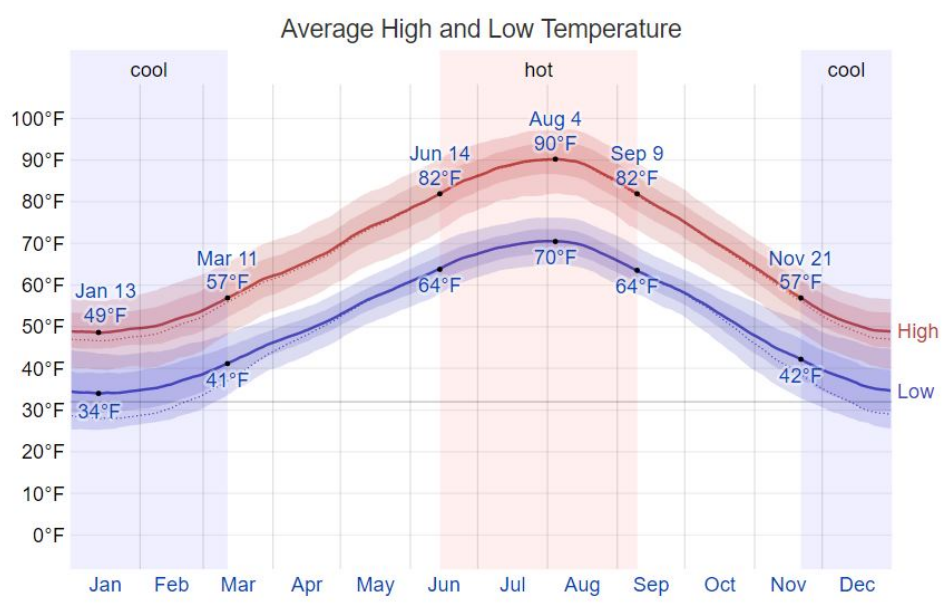

Fig. 10. The daily average high (red line) and low (blue line) temperatures [28].

The average hours of annual sunshine in Tirana is 2544 [29]. Albania is a country heavily defined by its location. It is a small predominantly mountainous country in Southern Europe, facing the Adriatic and lonian seas within the Mediterranean Sea. Table 5 introduces some geographical statistics for Albania: 
Table 5. Some statistics about Albania [30].

\begin{tabular}{|c|c|}
\hline Item & Description \\
\hline Continent & Europe \\
\hline Location & $\begin{array}{l}\text { Southeast Europe; Western part of the Balkan } \\
\text { peninsula; surrounded by the Adriatic Sea and } \\
\text { Ionian Sea to the West, Macedonia to the East, } \\
\text { Greece to the South and Montenegro and } \\
\text { Kosovo to the North }\end{array}$ \\
\hline Coordinates & $41^{\circ} 00^{\prime} \mathrm{N} 20^{\circ} 00^{\prime} \mathrm{E}$ \\
\hline Area & $28,748 \mathrm{~km}^{2}$ \\
\hline Coastline & $362 \mathrm{~km}(225 \mathrm{mi})$ \\
\hline Population & $3,038,594(\# 137)$ \\
\hline $\begin{array}{l}\text { Population } \\
\text { density }\end{array}$ & $110.91 / \mathrm{km}^{2}$ \\
\hline GDP (PPP) & $\$ 33.90$ billion \\
\hline $\begin{array}{l}\text { GPD per } \\
\text { Capita }\end{array}$ & $\$ 11,900$ \\
\hline Climate & $\begin{array}{l}\text { Mild temperate: winters are cool, cloudy and } \\
\text { wet, while summers are hot, clear and dry, } \\
\text { although interior regions are usually cooler } \\
\text { and wetter }\end{array}$ \\
\hline
\end{tabular}

temperatures below zero during the winters (the coldest temperature recorded was $-26^{\circ} \mathrm{C}$ ). The valley of Albania in the summer is hot, averaging $35^{\circ} \mathrm{C}$. The climate of the country has a Mediterranean character and is distinguished by a great number of sunny days, approximately 290 days a year, in the North and in the East, and about 325 days in the South and Southwest [31]

In 2015 , there was a $2 \%$ loss in high voltage transmission and a $31.3 \%$ loss in distribution in Albania. The Albanian power sector needs a new policy to address problems and set future energy targets. Table 6 shows the transmission and distribution losses in Albania, 2014 and 2015 [32].

Table 6. Transmission and distribution losses in Albania, 2014 and 2015

\begin{tabular}{|l|l|l|l|l|}
\hline Country & \multicolumn{2}{|l|}{$\begin{array}{l}\text { Transmission } \\
\text { losses (\%) }\end{array}$} & \multicolumn{2}{l|}{$\begin{array}{l}\text { Distribution losses } \\
(\%)\end{array}$} \\
\hline Albania & 2014 & 20 & 2014 & $\begin{array}{l}20 \\
15\end{array}$ \\
& & 15 & & 31. \\
\hline Loss & 2.1 & 2 & 37.8 & 3 \\
\hline
\end{tabular}

The renewable power capacity additions in Albania $2015 / 2016$ is presented in the following table. As indicated in the table, the use of renewable energy in these related countries is still modest.

The territory located in the Western coast is influenced by a maritime weather, where the temperatures in winter barely dip below zero, while summers are warm. The Eastern region is influenced by continental air masses; it is not rare to record

Table 7. Renewable power capacity additions in Albania 2015/2016 [2].

\begin{tabular}{|c|c|c|c|c|c|c|c|}
\hline Country & Hydro & Wind & Solar & $\begin{array}{l}\text { Solid } \\
\text { biomass }\end{array}$ & Biogas & Geothermal & Total \\
\hline Albania & 5.0 & 0.0 & 0.0 & 0.0 & 0.0 & 0.0 & 5.0 \\
\hline FYROM of Macedonia & 25.7 & 0.0 & 1.9 & 0.0 & 4.0 & 0.0 & 31.6 \\
\hline Bosnia and Herzegovina & 83.8 & 0.0 & 9.0 & 0.3 & 1.0 & 0.0 & 94.0 \\
\hline Montenegro & & & & & & & 0.0 \\
\hline
\end{tabular}

Table 8. Daily average solar radiation in $\left(\mathrm{kJ} / \mathrm{m}^{2}\right)$ [33]

\begin{tabular}{|l|l|l|l|l|l|l|l|l|l|l|l|l|}
\hline $\begin{array}{l}\text { City } \\
\text { Name }\end{array}$ & Jan. & Feb. & March & April & May & June & July & August & Sept. & Oct. & Nov. & Dec. \\
\hline Peshkopia & 9813 & 11584 & 13952 & 15127 & 17192 & 19225 & 20704 & 19815 & 18838 & 14189 & 1261 & 11566 \\
\hline Shkodra & 10857 & 12316 & 14119 & 15771 & 17425 & 19253 & 20836 & 20069 & 18855 & 14450 & 12977 & 12235 \\
\hline
\end{tabular}




\begin{tabular}{|l|c|c|c|c|c|c|c|c|c|c|c|c|}
\hline Durres & 13205 & 13523 & 14347 & 17604 & 18637 & 20228 & 22277 & 23199 & 20305 & 17750 & 15347 & 14677 \\
\hline Tirana & 12066 & 13292 & 14243 & 16007 & 18555 & 20538 & 21598 & 21896 & 19854 & 16564 & 13604 & 13250 \\
\hline Vlora & 14239 & 13894 & 13733 & 17726 & 19207 & 21376 & 22926 & 24093 & 23217 & 19791 & 17799 & 15347 \\
\hline Saranda & 12868 & 15445 & 16633 & 18511 & 20405 & 22758 & 23443 & 24101 & 23237 & 17390 & 16857 & 14820 \\
\hline
\end{tabular}

Table 8 introduces the average solar irradiation for the main cities in Albania. The data shows that solar energy is promising, especially in spring, summer and autumn.

Recently, Albania implemented the "Country Program of Albania" under the Global Solar Water Heating Market Transformation and Strengthening Initiative by the Government (a cooperation between the Ministry of Energy and Industry, the Ministry of Environment and the UNDP) which began in 2010 [34].

\subsection{Banja floating solar plant in Albania}

In the past decade, the use of renewable energy resources, particularly solar energy, in Albania has increased. For example, in September 2016, Norwegian Statkraft hydropower and wind company officially opened Banja hydropower cascade plants along the Devoll River in southeast Albania. Banja Lake as shown in Fig. 11 is located in Cerrik Municipality in the Elbasan province, $65 \mathrm{Km}$ Southeast Albania's capital Tirana. Table 9 presents some statistics of the Banja hydropower plants.

Table 9. Some statistics of the Banja hydropower plants [35]

\begin{tabular}{|c|c|c|}
\hline $\begin{array}{l}\text { Production } \\
\text { Power (MW) }\end{array}$ & $\begin{array}{l}\text { Dam height } \\
\text { (m) }\end{array}$ & $\begin{array}{l}\text { Total Volume } \\
\text { Covering an Area }\end{array}$ \\
\hline $\begin{array}{ll}700 & \text { GWh } \\
256 & \end{array}$ & 80 & $\begin{array}{l}391 \text { billion litres } \\
14 \mathrm{Km}^{2}\end{array}$ \\
\hline
\end{tabular}

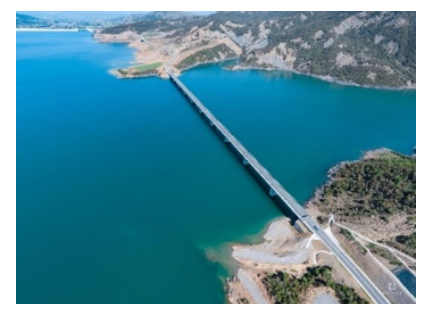

Fig. 11. General view of the Banja Lake in Albania [36-37].

Norway's Statkraft is entering the final stage of its second hydropower plant along the Devoll River, Moglice. Both projects form part of the comprehensive Devoll Hydropower project, which is estimated to cost $€ 535$ million for a total capacity of $256 \mathrm{MW}$. The aim of the investment is to boost electricity generation by 20 percent in the country [35].

Statkraft has relied on Ocean Sun AS, a Norwegian floating solar technology developer, to construct a floating solar plant with a maximum capacity of $2 \mathrm{MW}$ (4 floating units with a capacity $0.5 \mathrm{MW}$ ) in the Banja Lake, as demonstrated in Figs 12, each costing about EUR 2.3 million or \$2.6 million [38].

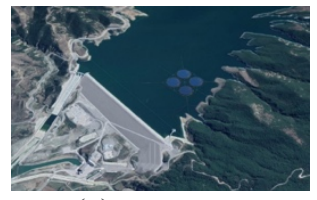

(a)

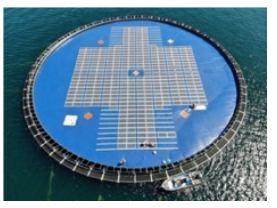

(b)
Fig. 12. The floating solar plant park will consist of 4 floating units (a) of 0.5 MW each (b) in the Banja Lake in Albania [39].

In addition, KESH is also developing new generation projects in the field of renewable and sustainable energy systems, such as wind and PV systems. The first project deals with the the installation of floating PVs on Vau i Dejës Reservoir, with a capacity of $12.9 \mathrm{MW}$, in 2019 [40].

\section{Advantages of floating solar photovoltaic (PV) [41]:}

- Opens new opportunities for boosting solar generating capacity

- Uses existing electricity transmission systems at hydropower sites

- Close to demand centers

- Improves energy yield due to the cooling effects of water and the decreased presence of dust

- Suitable for rural and desert communities

- Reduces evaporation from water reservoirs

- Improves water quality due to decreased algae growth

- $\quad$ Reduces or eliminates the shading of panels by their surroundings

- $\quad$ Easy installation and deployment in sites

Disadvantages of floating solar:

- Expensive

- $\quad$ Limited use

\section{Socioeconomic benefits [42-45, 51]:}

- Creates job opportunities

- Encourages graduate engineers and technicians to work in the PV systems field

- Develops a solar energy market

- Keeps and protects the environment

- Supports the education sector

- Enhances clinics in rural and mountainous areas

- Decreases migration from rural and mountainous areas to urban centers

- Expands the PV water pumping system in irrigation

- Increases the number of small businesses

- Increases tourism to rural and mountainous areas

- Improves the living conditions of rural populations 


\section{Recommendations:}

- Expanding the use of solar water heating panels

- Expanding the use of solar energy in the irrigation sector

- Eliminating taxation for all green energy technology

- Investing more in renewable resources

- Learning from the experience of leading countries in solar energy in the region

- Teaching about renewable energy in universities, institutes and schools

- Increasing community awareness of the importance of solar energy

- Motivating residential consumers to use PV systems widely

- Creating new photovoltaic farms

- Improving solar energy policies and regulations

- Developing technical standards for interconnection.

\section{Lessons learned [2, 46-51]:}

- Prioritizing the most efficient PV modules

- Comparing the efficiency metrics for different suppliers (greater electricity generation)

- PV modules certification - there are several various standards to selecting the best module

- PV module output - over time, the efficiency of the PV module decreases. Customers must select the best PV panels, taking into account the inspection for panel degradation and its warranty

- Expanding customer's use of PV technology, such as solar ovens, solar cellphone chargers, solar powered tents and backpacks, etc.

- Focusing on the growth of solar energy technology market

- Broadening the use of solar energy, especially in the field of heating

- Addressing the lack of investment in renewable energy

- Addressing the scarcity of scientific research in the field of renewable energy in Albania

- Designing and installing PV systems or solar farms, while ensuring a solid design and installation and high quality components to enhance the system's performance

- Ensuring a PV system exploitation and the good use of PV components to increase the longevity of the system

\section{Discussion}

Expanding the use of renewable energy resources requires more investments, governmental support, enhancement from international or regional renewable energy agencies, donors and customers. Developing countries need regional and international support to raise awareness of the importance of the application and optimal exploitation of renewable energy resources. According to the analysis of ground-based observations and satellite data collected by NASA, 2016 ranks as the warmest year on record, reaching $0.99^{\circ} \mathrm{C}$ as indicated in Fig. 13, while in 2017 reached of $0.9^{\circ} \mathrm{C}$ [52]. The first of half of 2016 set a record as the warmest months globally, according to statistics which date back to 1880 . Therefore, policymakers should prioritize the preservation of the planet by reducing heat emission as well as visible and invisible environmental pollution. Several steps to reduce heat emission and pollution include:

- Increasing the use of renewable energy resources and decreasing the use of finite energy production systems

- Recycling environmental pollutants

- Improving waste management plans

- Leaving your car at home twice a week

- Designing homes supported by renewable energy generation systems, such as solar or wind energy

- Increasing investments in the field of renewable energy production

- Raising awareness about climate change

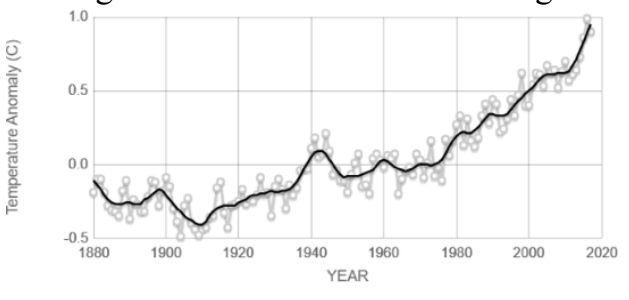

Fig. 13. Global land-ocean temperature index [52].

By studying the renewable energy sector in Albania, we found that this sector is developing by the day, but it requires greater support from donors and leading countries in the field.

\section{Conclusion}

This paper illustrated the renewable energy sector in the Southeastern European Countries. Solar energy in this area is explored and analyzed. We focused on the PV systems sector in Albania as a case study of this study where, we introduced warmer seasons, monthly temperature, and renewable generation capacities by energy source. The map of the average annual download surface solar irradiation in the related area is presented. The top of five European solar market are introduced. We discussed and analyzed the solar potential in Albania and the development of PV market as well. This paper concentrated on new floating solar projects in two different areas in Albania: Banja Lake and KESH. Finally, we touched on socioeconomic benefits of this study, some recommendations are included as well. The lessons learned were taken into consideration at the end of this study.

\section{Funding}

This research did not receive any specific grant from funding agencies in the public, commercial or non-profit sectors.

Conflicts of interest: none.

\section{References}

[1] Brian Dunbar. National Aeronautics and Space Administration NASA Official, https://www.nasa.gov/mission_pages/sdo/science/ 

solar-irradiance.html; 2018 [Accessed 27 July 2018].

[2] REN21. Renewables 2017 Global Status Report. Paris: REN21 Secretariat; 2017. ISBN 978-39818107-6-9. $<$ http://www.ren21.net/wpcontent/uploads/2017/06/178399_GSR_2017_Full_Report_0621_Opt.pdf $>$. [Accessed on 02 May 2018]

[3] NREL Transformation Energy. Solar photovoltaic technology basics, https://www.nrel.gov/workingwithus/rephotovoltaics.html; 2018 [Accessed 07 August 2018].

[4] Steve Cole and Darryl Waller. NASA releases detailed global climate change projections, NASA Headquarters and NASA's Research Center; June 8, 2015, https://www.nasa.gov/pressrelease/nasa-releases-detailed-globalclimate-change-projections; 2015. [Accessed on 13 June 2019].

[5] NASA. National Aeronautics and Space Administration Goddard Institute for Space Studies. April 2018 was Third Warmest April on Record, Posted May 2018 https://data.giss.nasa.gov/gistemp/news/20180516 /; 2018 [Accessed 12 July 2018].

[6] Shravan K. Chunduri, and Michael Schmela TAIANGNEWS. Asian Photovoltaic Industry Association, Advanced solar module technology; Edition 2017, $<$ http://www.apvia.org/upload/file/TaiyangNews Report_Advanced_Solar_Module\%20Technology 2017_download_version.pdf $>$. [Accessed on 05 May 2018].

[7] European Union and IRENA. Renewable Energy for the European Union, Based on REmap analysis, ISNB 978-92-9260-007-5; February 2018. Downloaded on 30.07.2018. $<$ https://www.irena.org//media/Files/IRENA/Age ncy/Publication/2018/Feb/IRENA_REmap_EU_2 018.pdf $>$. [Accessed on 30 July 2018]

[8] Giovanni Mazzanti, Ezio Santini, Donatella Zaccagnini. Towards grid parity of solar energy in Italy: the payback time trend of photovoltaic plants during the Last Years. pp 1-8, 2012. IEEE, DOI: 10.1109/PESGM.2012.6345426.

[9] Stelios Kazadzis et al.. Long-term series and trends in surface solar radiation in Athens, Greece. Atmospheric chemistry and physics, 18, pp 2395-2411. https://doi.org/10.5194/acp-182395-2018, 2018.

[10] Roberto Local Arantegui, Arnulf Jäger-Waldu. Photovoltaics and wind status in the European Union after the Paris Agreement. Renewable and Sustainable Energy Reviews 81 (2018) 24602471.

http://dx.doi.org/10.1016/j.rser.2017.06.052; 2018.

[11] Ehsanul Kabir, Pawan Kumar, Sandeep Kumar, Adedeji Adelodun, Ki-Hyun Kim. Solar energy: potential and future prospects. Renewable and Sustainable Energy Reviews 82 (2018) 894-900.

http://dx.doi.org/10.1016/j.rser.2017.09.094; 2018.

[12] Frankfurt School-UNEP Centre for Climate \& Sustainable Energy Finance (FS-UNEP Centre) and Bloomberg New Energy Finance (BNEF), Global Trends in Renewable Energy Investment 2018 (Frankfurt: April 2018), p. 12; 2018 $<$ http://fs-unepcentre.org/sites/default/files/publications/gtr2018 v2.pdf $>$. [Accessed on 15 July 2018].

[13] IEA international energy agency. Snapshot of global photovoltaic markets, Photovoltaic power systems programe, report IEA PVPS T1-33:2018, ISBN 978-3-906042-72-5, page 4; 2018 $<$ http://www.iea-

pvps.org/fileadmin/dam/public/report/statistics/IE A-PVPS_-_A_Snapshot_of_Global_PV_-_19922017.pdf $>$. [Accessed on 07 August 2018]

[14] IRENA. Renewable capacity statistics 2018. ISBN: 978-92-9260-057-0 (PDF); 2018. $<$ https://www.irena.org//media/Files/IRENA/Agency/Publication/2018/M ar/IRENA_RE_Capacity_Statistics_2018.pdf $>$. [Accessed on 09 August 2018]

[15] Jäger-Waldau. European Commission. JRC Science for policy report; PV status report 2016. Pdf, ISBN 978-92-79-63055-2 ISSN 1831-9424 doi:10.2790/682995; 2016 , $<$ http://publications.jrc.ec.europa.eu/repository/bit stream/JRC103426/ldna28159enn.pdf>.

[Accessed on 10 September 2018]

[16] Jäger-Waldau, A. European Commission, JRC science for policy report, PV Status Report, PDF, ISBN 978-92-79-74071-8 ISSN 1831-9424 doi:10.2760/452611 2017; 2017,

$<$ http://publications.jrc.ec.europa.eu/repository/bitst ream/JRC108105/kjna28817enn.pdf $>$. [Accessed on 11 August 2018]

[17] Arnulf Jäger-Waldau. The rooftop potential for systems in the European Union to deliver the Paris agreement. Spring 2018. http:/www.europeanenergyinnovation.eu/Articles /Spring-2018/The-Rooftop-Potential-for-PVSystems-in-the-European-Union-to-deliver-theParis-Agreement. [Accessed on 02 September 2018].

[18] Solar Power Europe. Solar Market Update Europe 2017. Annual solar installations 2017 in Europe, 2017. $<$ http://files.constantcontact.com/15d8d5a7001/ce 0e1a9d-15ea-4dbb-ad1f-3c4e6d7fafa7.pdf $>$. [Accessed on 07 June 2018].

[19] Green Rhino Energy. Solar Power radiation, Annual Solar Irradiance, Intermittency and Annual Variations. Downloads: Annual variation of insolation in Kassel, Germany (source: BP)

http://www.greenrhinoenergy.com/solar/radiation/e mpiricalevidence.php. [Accessed on 1 August 2018].

[20] Stefan Dunjic, Simon Pezzutto, Alyona Zubaryeva. Renewable energy development trends in the Western Balkan. Renewable and Sustainable Energy Reviews 65 (2016) 1026- 
1032.

http://dx.doi.org/10.1016/j.rser.2016.05.051.

[21] Klaus Jäger, Olindo Isabella, Arno Smets, René Swaaij, Miro Zeman. Solar energy fundamentals, Technology, and Systems. Delft University of Technology, the Netherlands. pp 37, 38, 39, 45 and 46; 2014. https://courses.edx.org/c4x/DelftX/ET.3034TU/as set/solar_energy_v1.1.pdf.

[22] Rafael C. Gonzalez and Richard E. Woods. Digital Image Processing, 4th Edition. Pearson/Prentice Hall, 2018.

[23] Balkan Green Foundation. Balkan energy overview. Balkan energy prospect, June 2017, (Table 2. RES target fulfillments (Albania, BiH, Kosovo).

2017

$<$ http://balkangreenfoundation.org/file/repository/ Balkan_Energy_Overview.pdf $>$. [Accessed on 24 September 2018].

[24] Renewable energy resources and energy efficiency in Albania. <http://aea-al.org/wpcontent/uploads/2012/04/RENEWABLE-

ENERGY-ALBANIA.pdf $>$. 2012. [Accessed on 24 September 2018].

[25] Albania Energy Association (AEA). Albania Solar Energy, http://aea-al.org/albania-solarenergy/; 2013 [Accessed on 21 September 2018].

[26] SOLARGIS. Download solar resource maps and GIS data $180+$ Countries, Selected region Albania, https://solargis.com/maps-and-gisdata/download/albania. [Accessed on 21 September 2018].

[27] List of mountains in Albania, https://en.wikipedia.org/wiki/List_of_mountains_ in_Albania. [Accessed on 22 September 2018].

[28] Average Weather in Koplik. Average high and low temperature, https://weatherspark.com/y/84415/AverageWeather-in-Koplik-Albania-Year-Round. [Accessed on 15 September 2018].

[29] Liz Osborn. Sunniest Cities in Europe, https://www.currentresults.com/WeatherExtremes/Europe/sunniest-cities.php. [Accessed on 28 August 2018].

[30] World atlas. Albanian Geography, https:/www.worldatlas.com/webimage/countrys/ europe/albania/alland.htm. [Accessed on 07 August 2018].

[31] Climate. Albania, http://www.albantours.info/en/welcome-toalbania/land-information/climate.html, (SHUKALB: Water Supply and) Sewerage Utility of Albania (FB11); Tirana, 2014 [Accessed on 12 September 2018].

[32] European Commission. Brussels, 9.11.2016 SWD (2016) 364 final. Commission Staff Working Document, Albania 2016 Report, Communication from the Commission to the European Parliament, the Council, the European Economic and Social Committee and the Committee of the Regions 2016 Communication on EU Enlargement Policy, $\operatorname{COM}(2016) 715$ final; 2016. <https://ec.europa.eu/neighbourhood- enlargement/sites/near/files/pdf/key_documents/2 $016 / 20161109$ report_albania.pdf $>$. [Accessed on 10 September $\overline{2} 018]$.

[33] Albania overview; $<$ http://www.akbn.gov.al/wpcontent/uploads/2013/11/images_pdf_publikime_ Broshura_Energjite_e_Rinovueshme.pdf $>$. [Accessed on 25 August 2018].

[34] UNDP. Empowered lives Resilient nations. The Country Programme of Albania under the Global Solar Water Heating Market Transformation and Strengthening Initiative; Tirana March 2017.<http://www.al.undp.org/content/dam/albani a/docs/misc/Best $\% 20$ Practice $\% 20$ from $\% 20 \mathrm{SWH}$ \%20Project_Eng.pdf $>$. [Accessed on 17 August 2018].

[35] https://www.statkraft.com/energy-sources/Powerplants/albania/banja/

[36] https://invest-in-albania.org/wpcontent/uploads/banja-HPP-devoll.jpg

[37] https://invest-in-albania.org/statkraft-submitsrequest-for-floating-solar-power-plant-in-banjalake/

[38] https:/www.offgridenergyindependence.com/arti cles/16794/floating-solar-plant-in-albania

[39] https://marineenergy.biz/wpcontent/uploads/2019/03/ocean-sun-to-deliverfloating-solar-plant-for-statkraft-in-albania1024x767.jpg

[40] Albanian power corporation (KESH J.S.C), climate risk management plan, December 2018, http://www.kesh.al/Files/CLIMATE\%20RISK\%2 0MANAGEMENT\%20PLAN\%202018.pdf.

[41] Where sun meets water. Floating solar market report. Executive summary. Solar Energy Research Institute of Singapore (SERIS) at the National University of Singapore (NUS), under contract from the World Bank, 2018. http://documents.worldbank.org/curated/en/57994 1540407455831/pdf/131291-WP-REVISEDP161277-PUBLIC.pdf [Accessed on 17 April 2019].

[42] Hadwan M, Alkholidi A. Solar power energy solutions for Yemeni rural villages and desert communities. Renew Sustain Energy Rev 2016; 57:838-49. http://dx.doi.org/ 10.1016/j.rser.2015.12.125.

[43] Alkholidi A. G. Renewable energy solution for electrical power sector in Yemen. International Journal of Renewble Energy, Res 2013; Vol. 3, No. (4): 803-11, Online ISSN: 1309-0127. https:/www.researchgate.net/publication/259758 984 Renewable_Energy_Solution_for_Electrical Power_Sector in_Yemen.

[44] Elieser Tarigan. Simulation and feasibility studies of rooftop PV system for university campus buildings in Surabaya, Indonesia. International Journal of Renewable Energy Research, Vol.8, No.2, June, 2018. https://core.ac.uk/download/pdf/159614505.pdf 
Abdulsalam Alkholidi and Habib Hamam, Vol.3, No.2, June, 2019

[45] Fahad Almasoudi et al. Simulation and performance comparison of $\mathrm{Si}$ and $\mathrm{SiC}$ based on a proposed $\mathrm{H} 6$ inverter for PV grid-tied applications. International Journal of Renewable Energy Research, Vol.8, No.2, June, 2018. https://www.ijrer.org/ijrer/index.php/ijrer/a rticle/download/7560/pdf.

[46] Khalid Anwar and Sandip Deshmukh. Assessment and mapping of solar energy potential using artificial neural network and GIS technology in the Southern part of India. International Journal of Renewable Energy Research, Vol.8, No.2, June, 2018. https://www.ijrer.org/ijrer/index.php/ijrer/a rticle/download/7674/pdf.

[47] Parimal S. Bhambar et al. Solar thermal desalination: A sustainable alternative for Sultanate of Oman. International Journal of Renewable Energy Research, Vol.8, No.2, June, 2018.

https://www.ijrer.org/ijrer/index.php/ijrer/article/v iew/7209/pdf.

[48] Parimal S. Bhambar et al. Solar thermal desalination: A sustainable alternative for Sultanate of Oman. International Journal of Renewable Energy Research, Vol.8, No.2, June, 2018.

https://www.ijrer.org/ijrer/index.php/ijrer/article/v iew/7209/pdf.
[49] Ilhan Keskin and Gurkan Soykan. Reduction of peak power consumption by using photovoltaic panels in Turkey. 2017 IEEE 6th International Conference on Renewable Energy Research and Applications

(ICRERA). DOI: 10.1109/ICRERA.2017.8191187.

[50] Republic of Albania. Economic reform program 2018-2020, $31 \quad$ January 2018. https://financa.gov.al/wpcontent/uploads/2018/06/Economic_Reform_Pro gramme_2018-2020-1.pdf [Accessed on 17 April 2019].

[51] REN21. 2018. Renewables 2018 Global Status Report (Paris: REN21 Secretariat). ISBN 978-39818911-3-3. $\quad$ http://www.ren21.net/wpcontent/uploads/2018/06/17-

8652_GSR2018_FullReport_web_final_.pdf [Accessed on 17 April 2019].

[52] NASA. Global climate change, Vital signs of the planet, Global temperature, Global land-ocean temperature index, Data source: NASA's Goddard Institute for Space Studies (GISS), NASA's Goddard Institute for Space Studies (GISS). Credit: NASA/GISS

https://climate.nasa.gov/vital-signs/globaltemperature/; 2017 [Accessed on 09 September 2018]. 